\title{
Burrow forms, growth rates and feeding rates of wood-boring Xylophagaidae bivalves revealed by micro-computed tomography
}

\section{Diva J. Amon 1,2,3*, Daniel Sykes ${ }^{4}$, Farah Ahmed ${ }^{4}$, Jonathan T. Copley ${ }^{2}$, Kirsty M. Kemp ${ }^{5}$, Paul A. Tyler ${ }^{2}$, Craig M. Young ${ }^{6}$ and Adrian G. Glover ${ }^{1}$}

${ }^{1}$ Life Sciences Department, Natural History Museum, London, UK

${ }^{2}$ Ocean and Earth Science, National Oceanography Centre, Southampton, University of Southampton, Southampton, UK

${ }^{3}$ Department of Oceanography, University of Hawai'i at Manoa, Honolulu, HI, USA

${ }^{4}$ Imaging and Analysis Centre, Natural History Museum, London, UK

${ }^{5}$ Institute of Zoology, Zoological Society of London, London, UK

${ }^{6}$ Oregon Institute of Marine Biology, University of Oregon, Charleston, OR, USA

\section{Edited by:}

Ricardo Serrão Santos, University of the Azores, Portugal

Reviewed by:

Erik Cordes, Temple University, USA

Americo Montiel, Universidad de

Magallanes, Chile

*Correspondence:

Diva J. Amon, Department of Oceanography, University of Hawai'i

at Manoa, 1000 Pope Road

Honolulu, HI 96822, USA

e-mail:divaamon@hawaii.edu
Wood sinking into the deep sea is often colonized by species of the bivalve subfamily Xylophagaidae; specialist organisms that bore into it and digest cellulose with the aid of symbiotic bacteria. Very little is known about the nature of Xylophagaidae borings, Xylophagaidae abundances and population size structures, their rates of growth and their consumption rates of wood. To investigate this, several sets of experimental wood packages were deployed and retrieved: two sets from two seamount sites on the Southwest Indian Ridge $(732-750 \mathrm{~m})$, one from the Mid-Cayman Spreading Centre in the Caribbean $(4773 \mathrm{~m})$, and three sets from $500 \mathrm{~m}$ in the Tongue of the Ocean, Bahamas. The wood samples were scanned using X-ray micro-computed tomography (micro-CT). The wood at each deployment site was colonized by a different species of xylophagaid. Making novel use of micro-CT images, the morphology of intact xylophagaid borings were shown to resemble Prince Rupert's Drops with "drop lengths" varying between species. Mean sizes of Xylophagaidae and mean minimum growth rates $\left(2.55-8.76 \mathrm{~mm}\right.$ year $\left.^{-1}\right)$ varied among species also. Rates of wood degradation were up to $60 \mathrm{~cm}^{3}$ per year per 100 individuals but in reality, this may have been an underestimate. This analysis has given insight into the importance of the subfamily Xylophagaidae with regard to wood remineralization in the deep sea.

Keywords: Xylophaga murrayi, Xylophaga depalmai, Xylophaga indica, Xyloredo nooi, wood fall, deep sea, boring

\section{INTRODUCTION}

With the exception of sites of autochthonous primary production such as hydrothermal vents, the food webs of the deep-sea floor are ultimately sustained by organic matter from the upper ocean. Although most allochthonous organic input to the deepsea floor is marine in origin, terrestrially-derived materials such as wood can provide major inputs, particularly at bathyal depths near forested regions or major river systems. Upon reaching the deep-sea floor, wood creates ephemeral patchy habitats that host distinct assemblages of fauna (Turner, 1973). These fauna colonize and congregate around the organic enrichment caused by the wood, using it as a food source, substratum and shelter (Turner, 1973, 1977; Wolff, 1979). Wood falls also have the ability to support chemosynthetic animals that are dependent on sulfide-rich conditions created by anoxia from organic loading of the immediate sediments (Duperron et al., 2008; Bernardino et al., 2010; Bienhold et al., 2013). Globally, the significance of wood falls to the overall energy budget of the deep-sea environment and carbon mineralization on the seafloor is still unquantified (Gage, 2003).
There are few data on the quantities of terrestrial plant matter entering the oceans worldwide, but it has been sufficient to allow the evolution of the diverse obligate wood-boring mollusks, the Xylophaga Turton 1822, the Xylopholas Turner 1972, and the Xyloredo Turner 1972 (Turner, 1955, 1972; Knudsen, 1961). There are more than 55 known species of Xylophagaidae (Pholadidae, Bivalvia) from around the world at depths from 0 to $7250 \mathrm{~m}$ (Knudsen, 1961; Turner, 2002; Voight, 2008, 2009; Voight and Segonzac, 2012). These opportunists bore into the wood using the toothed-ridged anterior edge of their shells as rasps before ingesting the wood particles and storing them in a caecum (Knudsen, 1961; Turner, 1973; Romey et al., 1994; Distel and Roberts, 1997). Wood then passes through the stomach and gut where it is digested with the aid of symbiotic bacteria, which may be capable of synthesizing enzymes such as cellulases as has been seen in teredinids (Distel and Roberts, 1997; Yang et al., 2009). Wood not only provides Xylophagaidae with nutrition but also shelter (Distel and Roberts, 1997).

Xylophagaidae is the most important subfamily that converts energy in refractory deep-sea wood and other plant material 
into more accessible forms: fecal matter for detritus feeders and tissue for predators and scavengers (Turner, 1973, 2002; Bienhold et al., 2013). These bivalves also function as habitat engineers by creating sulfidic conditions in the sediment, through their production of large amounts of fecal pellets, which attract chemosynthetic fauna (Bienhold et al., 2013). Despite the ubiquitous nature of this subfamily at wood falls, little is known about their ecology and life history, and for many species, the morphological description serves as the only record known thus far. As a result, even basic biological information such as growth rates is lacking (Romey et al., 1994; Harvey, 1996; Tyler et al., 2007; Voight and Segonzac, 2012; Romano et al., 2013), and there have been no studies on the rates of wood degradation by Xylophagaidae.

Xylophagaidae at wood falls are analogous to Osedax, the whale-bone-eating siboglinid, in that their boring activity breaks down and aids in the remineralization of the hard substrate of these habitats while also using them as a source of food via an endosymbiotic pathway (Rouse et al., 2004; Vrijenhoek et al., 2008; Glover et al., 2013). There are also similarities in the difficulty of observing the nature of these borings, as removing the animals necessitates physically destroying the borings. Several recent studies have used the technique of micro-computed tomography (micro-CT) to study the nature of Osedax borings in modern and fossil bones recovered from the seafloor (Higgs et al., 2010; Kiel et al., 2010; Higgs et al., 2011a,b). This method has allowed a more detailed understanding of the 3D morphology of borings, as well as permitting quantitative data to be collected on rates of bone degradation by direct measurement of the volumes of borings. In wood-boring mollusks, the x-ray method was first used in the 1950s in studies of Teredo shipworms to characterize the nature of their attack on ships and jetties (Crisp et al., 1953), but it has been rarely used in studies of deep-sea Xylophagaidae (Tyler et al., 2007) (Figure 1). However, even stereo $\mathrm{x}$-ray photographs provide poor information on the $3 \mathrm{D}$ nature of the borings and their volume in comparison with micro-CT (Figure 1).

In this study, we make the first comprehensive micro-CTbased investigation of Xylophagaidae borings from four species in two ocean basins. We investigate the 3D nature of the borings and visualize the preserved animals in situ while making quantitative

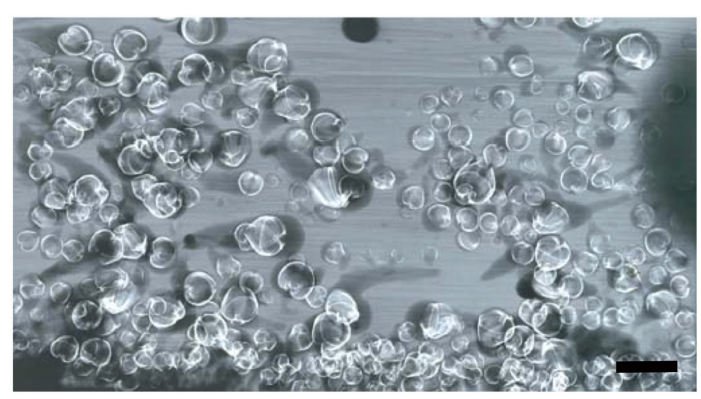

FIGURE 1 | X-radiographs of Xylophaga depalmai in wood. The calcified shells of $X$. depalmai individuals can be seen in white. Very few borings can be seen effectively. This figure is reproduced with changes from Tyler et al. (2007). Scale bar is $10 \mathrm{~mm}$.

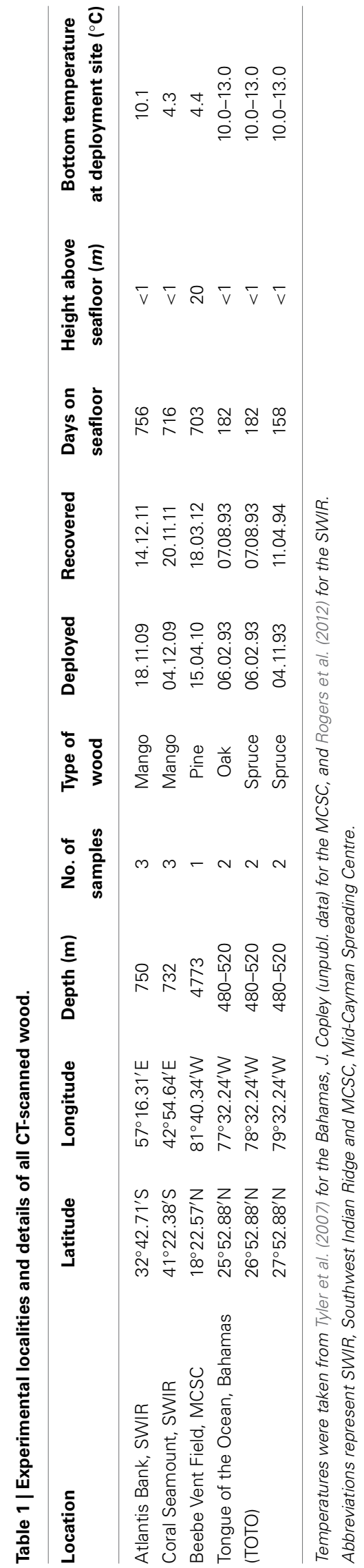


measurements of growth rates and the rates of degradation of wood by members of this subfamily. We test the hypotheses that different species found in varying locations have different growth rates and abundances, and that wood-degradation rates of xylophagaids vary between wood types, species, and location, with more wood being degraded per Xylophagaidae individual in warmer waters.

\section{MATERIALS AND METHODS \\ EXPERIMENTAL DEPLOYMENTS AND RECOVERIES}

Wood samples from the Southwest Indian Ridge (SWIR), the Mid-Cayman Spreading Centre (MCSC) in the Caribbean, and the Tongue of the Ocean (TOTO) in the Bahamas were analyzed. Full experimental protocols for the deployments on the SWIR and TOTO can be found in Amon et al. (in review) and Tyler et al. (2007) respectively. At the SWIR, mango wood was deployed for two years on two seamounts, Atlantis Bank and Coral Seamount, at $\sim 750 \mathrm{~m}$. At TOTO, spruce and oak planks $(14 \times 14 \times 1 \mathrm{~cm}$ approximately) were deployed at $\sim 480-520 \mathrm{~m}$ for $\sim 6$ months. Once recovered, the wood was transferred into buckets of chilled water and photographed. The deployments from TOTO were fixed in $80 \%$ ethanol and deposited in the Natural History Museum, London after some individuals were used for reproductive studies. The SWIR deployments were frozen at $-20^{\circ} \mathrm{C}$. The wood package deployed at the MCSC was within $0.5 \mathrm{~km}$ of the active Beebe Hydrothermal Vent Field (Connelly et al., 2012) at $4773 \mathrm{~m}$, and consisted of a block of three planks of pine wood at $20 \mathrm{~m}$ off the seafloor on a mooring that also had oceanographic instruments and whale bones attached. One boring was located on the MCSC deployment, which was sawn free from the rest of the wood, photographed and preserved in $100 \%$ ethanol. Bottom-water temperature was recorded at each deployment site (Table 1). A combination of previously-published and unpublished new samples were used in this study because intact deep-sea wood samples inhabited by Xylophagaidae are rare and this novel technique would be better tested using larger sample numbers. The morphology of Xylophagaidae from each wood location was examined to identify

Table 2 | Micro-CT scanning parameters of all wood samples.

\begin{tabular}{|c|c|c|c|c|c|}
\hline Sample & Sample code & $\begin{array}{c}\text { Voltage } \\
\text { (kV) }\end{array}$ & $\begin{array}{l}\text { Number of } \\
\text { projection } \\
\text { images }\end{array}$ & $\begin{array}{c}\text { Resolution } \\
\text { ( } \mu \text { m per } \\
\text { pixel) }\end{array}$ & $\begin{array}{l}\text { Total volume of } \\
\text { sample }\left(\mathrm{mm}^{3}\right)\end{array}$ \\
\hline \multirow[t]{3}{*}{ Atlantis Bank, SWIR } & SWR06 & 180 & 3142 & 0.0762 & 947145 \\
\hline & SWR24 & 180 & 3142 & 0.0860 & 637386 \\
\hline & SWR37 & 180 & 3142 & 0.0913 & 860650 \\
\hline \multirow[t]{3}{*}{ Coral Seamount, SWIR } & SWR55 & 180 & 3142 & 0.0898 & 130213 \\
\hline & SWR56 & 180 & 3142 & 0.1006 & 998641 \\
\hline & SWR64 & 180 & 3142 & 0.0742 & 387103 \\
\hline Beebe Vent Field, MCSC & CAYMAN1 & 180 & 3142 & 0.0456 & 3181 \\
\hline \multirow[t]{6}{*}{ Tongue of the Ocean, Bahamas (TOTO) } & 1STOAKFEBAUG93_1 & 190 & 3142 & 0.1152 & 546046 \\
\hline & 1STOAKFEBAUG93_2 & 190 & 3142 & 0.1152 & 484910 \\
\hline & 2NDSPRUCEFEBAUG93_1 & 180 & 3142 & 0.1136 & 506524 \\
\hline & 2NDSPRUCEFEBAUG93_2 & 180 & 3142 & 0.1136 & 421234 \\
\hline & 2NDSPRUCENOV93APR94_1 & 180 & 3142 & 0.1136 & 337024 \\
\hline & 2NDSPRUCENOV93APR94_2 & 180 & 3142 & 0.1136 & 373467 \\
\hline
\end{tabular}

In all samples, amps were $200 \mu \mathrm{A}$ and exposure time per projection were $500 \mathrm{~ms}$.

Table 3 | Measurements of the Xylophagaidae populations.

\begin{tabular}{|c|c|c|c|c|c|c|c|c|c|}
\hline Species & Wood & $\begin{array}{l}\text { Days on } \\
\text { seafloor }\end{array}$ & $\begin{array}{c}n \text { (number of } \\
\text { specimens } \\
\text { measured) }\end{array}$ & $\begin{array}{l}\text { Minimum } \\
\text { diameter } \\
\text { (mm) }\end{array}$ & $\begin{array}{l}\text { Maximum } \\
\text { diameter } \\
\text { (mm) }\end{array}$ & $\begin{array}{c}\text { Mean } \\
\text { diameter } \\
(\mathrm{mm})\end{array}$ & $\begin{array}{c}\text { Modal } \\
\text { diameter } \\
(\mathrm{mm})\end{array}$ & $\begin{array}{c}\text { Mean abundance } \\
\text { (individuals } \\
\mathbf{d m}^{-3} \text { ) }\end{array}$ & $\begin{array}{l}\text { Mean } \\
\text { minimum growth } \\
\text { rate }\left(\mathrm{mmd}^{-1}\right)\end{array}$ \\
\hline Xylophaga cf. indica & Mango & 756 & 697 & 2.04 & 9.79 & 5.86 & 5.13 & 300 & 0.008 \\
\hline Xylophaga murrayi & Mango & 716 & 87 & 0.94 & 8.54 & 5.31 & 4.86 & 117 & 0.007 \\
\hline Xyloredo cf. nooi & Pine & 703 & 1 & - & - & $6.40^{*}$ & - & - & $0.009 *$ \\
\hline \multirow[t]{3}{*}{ Xylophaga depalmai } & Oak & 182 & 1489 & 0.97 & 8.80 & 4.12 & 2.26 & 1446 & 0.023 \\
\hline & Spruce & 182 & 1318 & 0.28 & 10.12 & 4.11 & 4.78 & 1445 & 0.022 \\
\hline & Spruce & 158 & 1089 & 0.50 & 8.56 & 4.13 & 3.97 & 1524 & 0.026 \\
\hline
\end{tabular}

Measurements with an asterisk $\left({ }^{*}\right)$ do not represent a mean measurement but rather are from the only specimen present in that sample. A dash (-) is placed where population measurements could not be made, as only one individual was present. 


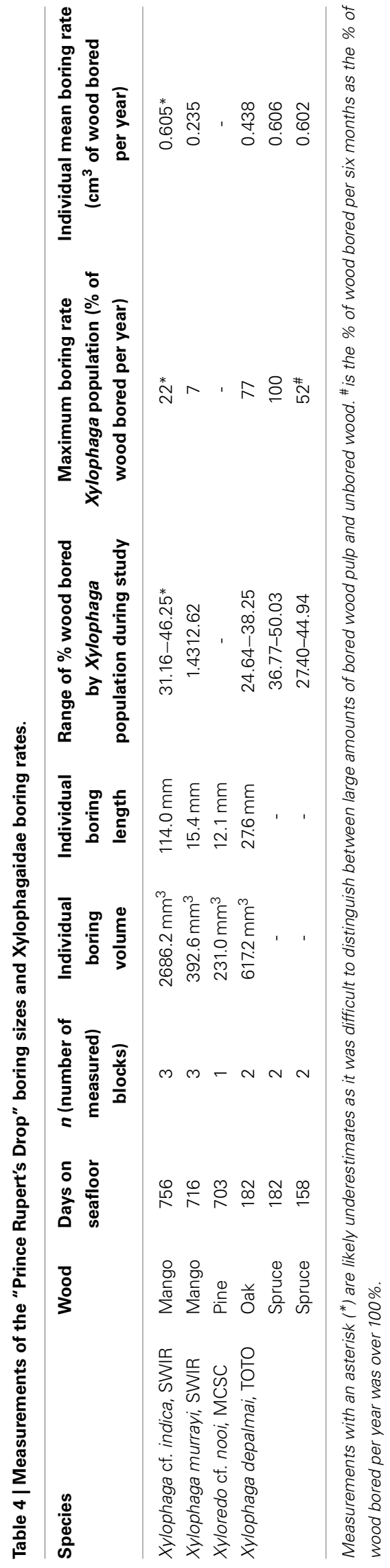

each species at the Natural History Museum, London, by light microscopy with a Zeiss V.20 stereomicroscope with AxioCam camera.

\section{MICRO-COMPUTED TOMOGRAPHY AND ANALYSIS OF SCANS}

Subsamples were sawn from three pieces of wood from each of the two SWIR locations to allow the samples to fit into the scanner. Six whole blocks from the TOTO samples were chosen for scanning. The 13 samples (Tables 1, 2) were scanned using the Nikon HMX ST 225 micro-CT (Nikon Metrology, Tring, UK). This system is equipped with a detector panel $(2000 \times 2000$ pixels $)$ with a maximum resolution of $5 \mu \mathrm{m} /$ pixel and a maximum energy of $225 \mathrm{kV}$. A tungsten target source and a scanning medium of air were used for each scan of the 13 specimens. Individual scanning parameters can be found in Table 2. Images acquired during the scanning process were subsequently reconstructed using the software CT Pro (Nikon Metrology, Tring, UK), which employs a modified version of the back-projection algorithm created by Feldkamp et al. (1984). This enabled the production of a volume image file that was opened in VG Studio Max 2.1 (Volume Graphic GmbH, Heidelberg, Germany) for each specimen. This program allowed the creation of a stack of grayscale bitmap images, which were then imported into the Drishti software suite (Limaye, 2006).

In Drishti, different transfer functions were created for xylophagaid shell, wood and air based upon the relative Xray absorption (a proxy for density) of each. Manual defining of each transfer function using the "mop carve" function in Drishti was needed to remove artifacts created during the scanning process, including all the air surrounding the wood during the scan. The specimens of Xylophaga depalmai were not imaged effectively; this may have been as a result of significant shell degradation since sampling in 1993/4, thus all the $X$. depalmai individual diameters in each piece of wood were supplied from the study published as Tyler et al. (2007). Volume measurements of the wood, air in borings, as well as diameters of every individual Xylophagaidae shell in each sample were measured using the "get volume" and "path length" function in Drishti (Tables 2-4). Numbers of individuals measured per species, as well as minimum growth rates, are also in Table 3. The minimum growth rates of the four xylophagaid species were calculated based on an assumption that settlement occurred on the first day of deployment. Whilst this is unlikely, it does provide a minimum growth rate that can be compared across the samples. The individual volumes were calculated manually from the diameters assuming that they were spherical.

All statistical analyses were performed in SPSS Statistics v. 20.0. The Kruskal-Wallis test was used to measure significant differences between Xylophagaidae abundances, sizes and growth rates for each species. The percentages of total wood volume bored, xylophagaid population rates of wood degradation and individual rates of wood degradation for each species were also compared. Also, temperature was correlated with Xylophagaidae abundances, sizes and individual xylophagaid rates of wood degradation. 


\section{RESULTS \\ COLONIZING XYLOPHAGAIDAE SPECIES AND MORPHOLOGY OF BORINGS}

The wood packages from the two localities on the SWIR were colonized by two species of Xylophaga: at Coral Seamount, Xylophaga murrayi Knudsen 1967 (Figures 2A,E, and Table 3) and at Atlantis Bank, Xylophaga cf. indica Smith 1904 (Amon et al., in review) (Figures 2D,H, and Table 3). The wood from the TOTO experiments was colonized by Xylophaga depalmai Turner 2002 (Tyler et al., 2007) (Figures 2B,F, and Table 3). The wood from the MCSC experiments was colonized by one specimen of Xyloredo cf. nooi Turner 1972 (Figures 2C,G, and Table 3). The X. cf. noo $i$ individual was not included in comparisons that consider the entire population.
Micro-CT revealed a characteristic 3D shape of the xylophagaid borings: an elongated teardrop, which could be described as akin to a "Prince Rupert's Drop," so named for the formation created by liquid glass dropped into water (Figure 3 ). There was however, some variation observed visually between species. $X y l o p h a g a$ murrayi and $X$. depalmai both have "Prince Rupert's Drop" borings but $X$. depalmai was larger (Figures 3B,C). The boring shapes for $X$. depalmai did not differ between spruce and oak. Xyloredo cf. nooi has a much shorter drop length (Figure 3D) whilst the boring of Xylophaga cf. indica has a very elongated "Prince Rupert's Drop" (Figure 3E and Table 4). The borings of Xylophagaidae are distinct from the borings created by terrestrial insects in wood; a reticulate network of thin tubes of generally equal width (not tapering to a point) was also revealed by the
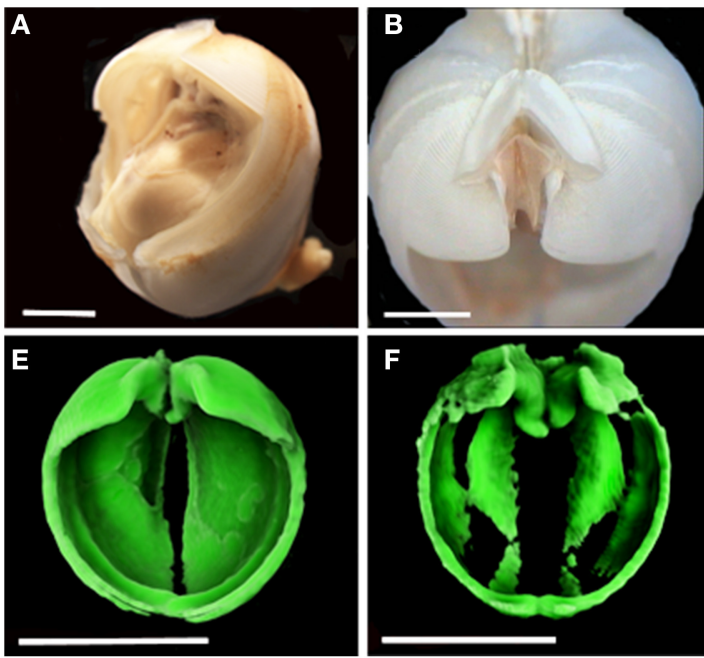

FIGURE 2 | Colonizing Xylophagaidae species. (A-D) were imaged using light microscopy and (E-H) were imaged using micro-CT. (A) Xylophaga murrayi; (B) Xylophaga depalmai; (C) Xyloredo cf. nooi; (D) Xylophaga cf. indica; (E) Xylophaga murrayi; (F) Xylophaga depalmai; (G) Xyloredo cf. nooi; (H) Xylophaga cf. indica. The individual
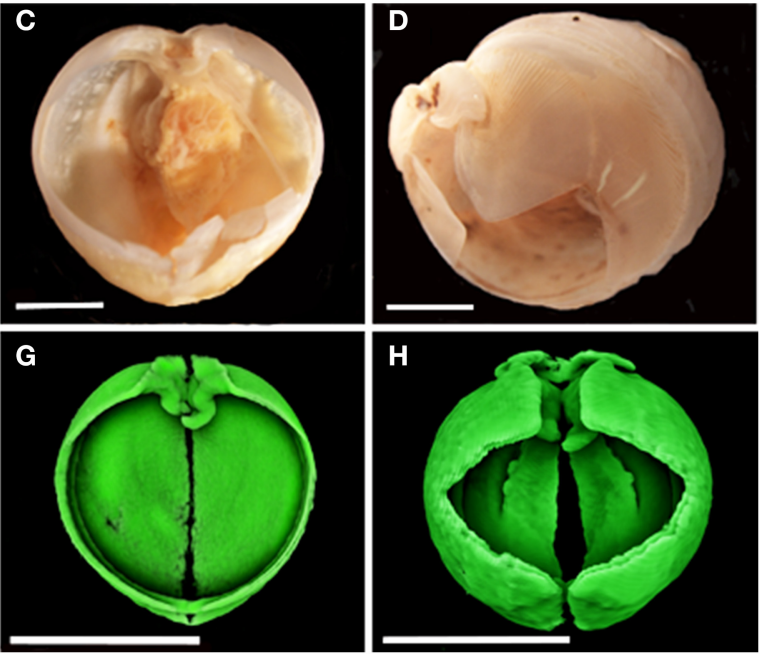

Xylophagaidae would be better resolved if smaller scans had been done. Xylophaga depalmai in (F) has not been imaged properly (only the densest parts of the shell can be seen) and this may be as a result of shell degradation over time. Scale bars for (A-D) are $2 \mathrm{~mm}$ (E-H) are $5 \mathrm{~mm}$
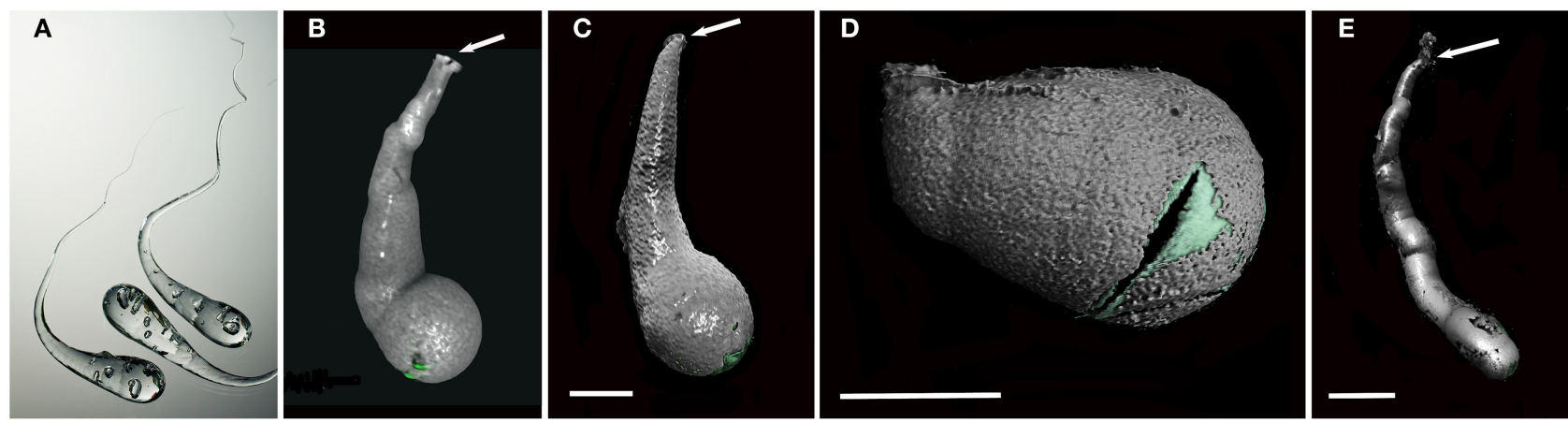

FIGURE 3 | Prince Rupert's drops and the typical boring morphologies of colonizing Xylophagaidae species. (A) Three Prince Rupert's Drops; (B) Xylophaga murrayi boring imaged using micro-CT; (C) Xylophaga depalmai boring imaged using micro-CT; (D) Xyloredo cf. nooi boring imaged using micro-CT; (E) Xylophaga cf. indica boring imaged using micro-CT. The Prince
Rupert's Drop is made from heating glass and allowing it to fall into water where it cools quickly. The image in (A) is credited to Gary Hodges, courtesy of The Corning Museum of Glass. All boring openings (B-E) are indicated by arrows. The transfer functions for Xylophagaidae shells (green) and air (gray) can be seen in (B-E). Scale bars for (B-D) are $5 \mathrm{~mm}$ and (E) is $20 \mathrm{~mm}$. 
micro-CT (Figure 4), hypothesized to have been created prior to deployment.

A characteristic boring produced by Xylophaga murrayi had a volume of $392.6 \mathrm{~mm}^{3}$ and a length of $15.4 \mathrm{~mm}$, for Xylophaga cf. indica, a volume of $2686.2 \mathrm{~mm}^{3}$ and a length of $114 \mathrm{~mm}$, and Xylophaga depalmai had a typical volume of $617.2 \mathrm{~mm}^{3}$ and a length of $27.6 \mathrm{~mm}$ (Figure 3 and Table 4). For Xyloredo cf. nooi, a volume of $231.0 \mathrm{~mm}^{3}$ and a length of $12.1 \mathrm{~mm}$ were observed (Figure 3 and Table 4). All four species' borings had apertures less than $1.0 \mathrm{~mm}$ in diameter, which lead into much wider borings (Figure 3 ). The borings in each piece of wood from the SWIR were very similar in orientation and extended in a similar direction (Figures 4-6). The Xylophaga individuals kept their borings separate and prevented burrows joining, unlike the probable terrestrial wood infestation (Figure 4). Xylophaga specimens within the borings did not appear to orient themselves in similar ways (Figure 7).

\section{ABUNDANCE AND POPULATION SIZE STRUCTURE}

Abundances of the Xylophaga in the wood from the Bahamas and SWIR were significantly different $(H=9.346, p=0.009)$ (Table 3). Xylophaga murrayi from Coral Seamount had the lowest mean abundance with $117 \pm 99.0$ individuals $\mathrm{dm}^{-3}$ and Xylophaga cf. indica from the Atlantis Bank had $300 \pm$ 114.3 individuals $\mathrm{dm}^{-3}$ (Table 3). Xylophaga depalmai in oak from TOTO had $1446 \pm 34.8$ individuals $\mathrm{dm}^{-3}$ while spruce contained the highest mean abundance, $1484.5 \pm 259.8$ individuals $\mathrm{dm}^{-3}$ (Table 3). There was no significant difference among the TOTO sample sets. A video showing the internal structures of a piece of wood colonized by $X$. depalmai can be accessed here: https://www.youtube.com/watch?v=9G3_qMYL7pM.

There was a significant difference in the mean sizes of the four species of Xylophaga from all 13 scanned pieces of wood $(H=9.703, p=0.021)$ but not within the populations of Xylophaga depalmai from different types of wood (Table 3). The mean diameter of Xylophaga murrayi recorded was $5.31 \pm$ $1.6 \mathrm{~mm}$, Xylophaga cf. indica was $5.86 \pm 1.5 \mathrm{~mm}$ and $X$. depalmai had mean diameters of $4.12 \mathrm{~mm}$ in oak $( \pm 1.3 \mathrm{~mm})$ and spruce $( \pm 1.5 \mathrm{~mm})$ (Table 3$)$. The only specimen of Xyloredo cf. noo $i$ had a diameter of $6.40 \mathrm{~mm}$ (Table 3 ). The modal diameters differed slightly from the mean diameters (Figure 8 and Table 3). The population structures of $X$. cf. indica and $X$. depalmai were unimodal suggesting that only one recruitment event had occurred and was not continuous (Figure 8). However, for X. murrayi, some evidence of a bimodal distribution was observed in two of the three samples, but this cannot be considered strong evidence for more than one recruitment event (Figure 8A).

\section{GROWTH RATES}

For Xylophaga murrayi, the bimodal size structure creates the possibility that more than one recruitment event has occurred, and as such the minimum growth rates that follow may be inaccurate for

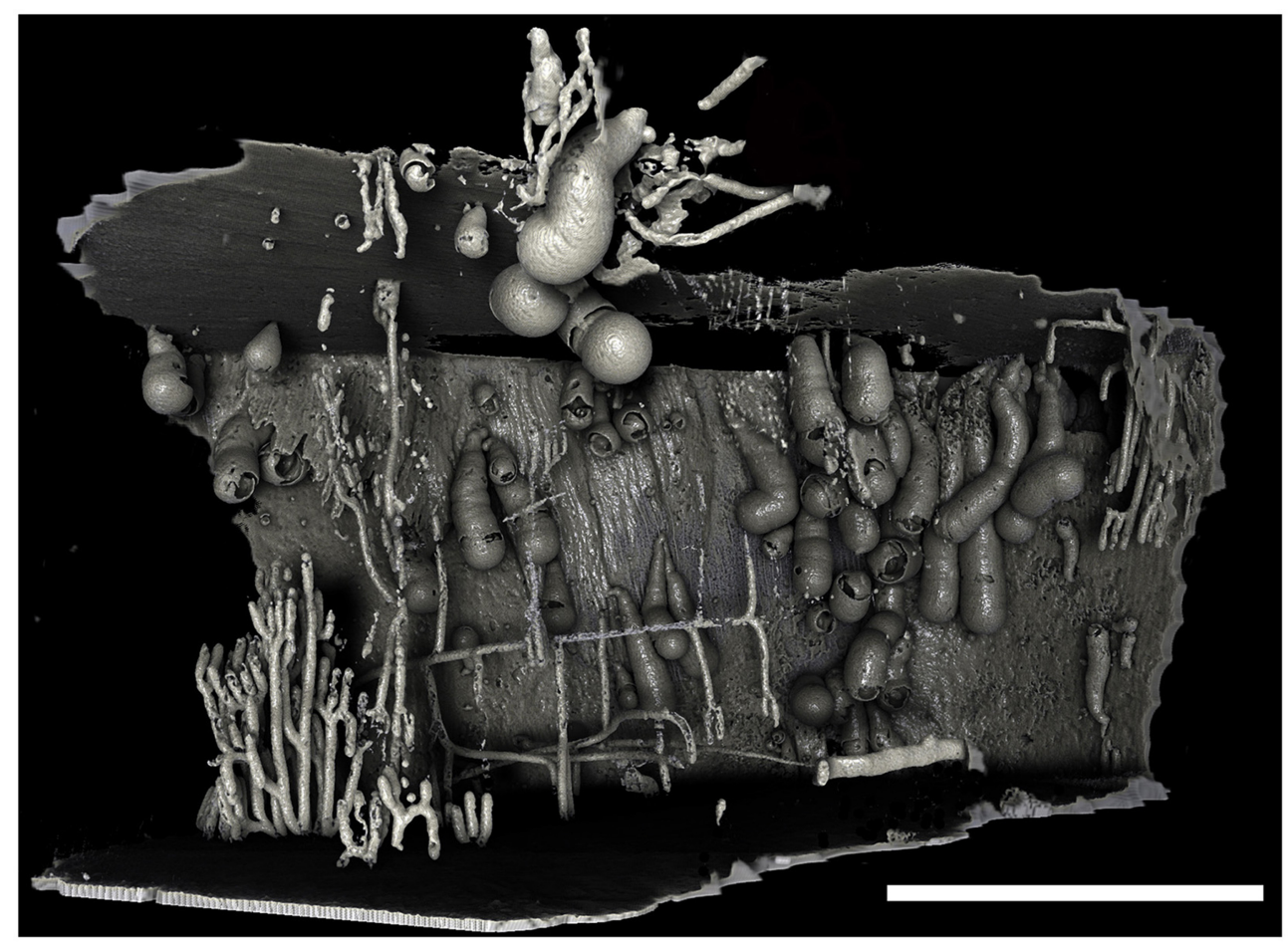

FIGURE 4 | Borings of a population of Xylophaga murrayi. Only the transfer function for air can be seen in this image. Some of the air surrounding this piece of wood was purposefully left in to allow the reader to gauge the shape and size of the wood and the relative position of the borings within the wood. The thin pipe-like boring network seen to the left was not created by Xylophaga and may belong to wood-boring terrestrial insects that attacked the wood when on land. Scale bar is $30 \mathrm{~mm}$. 


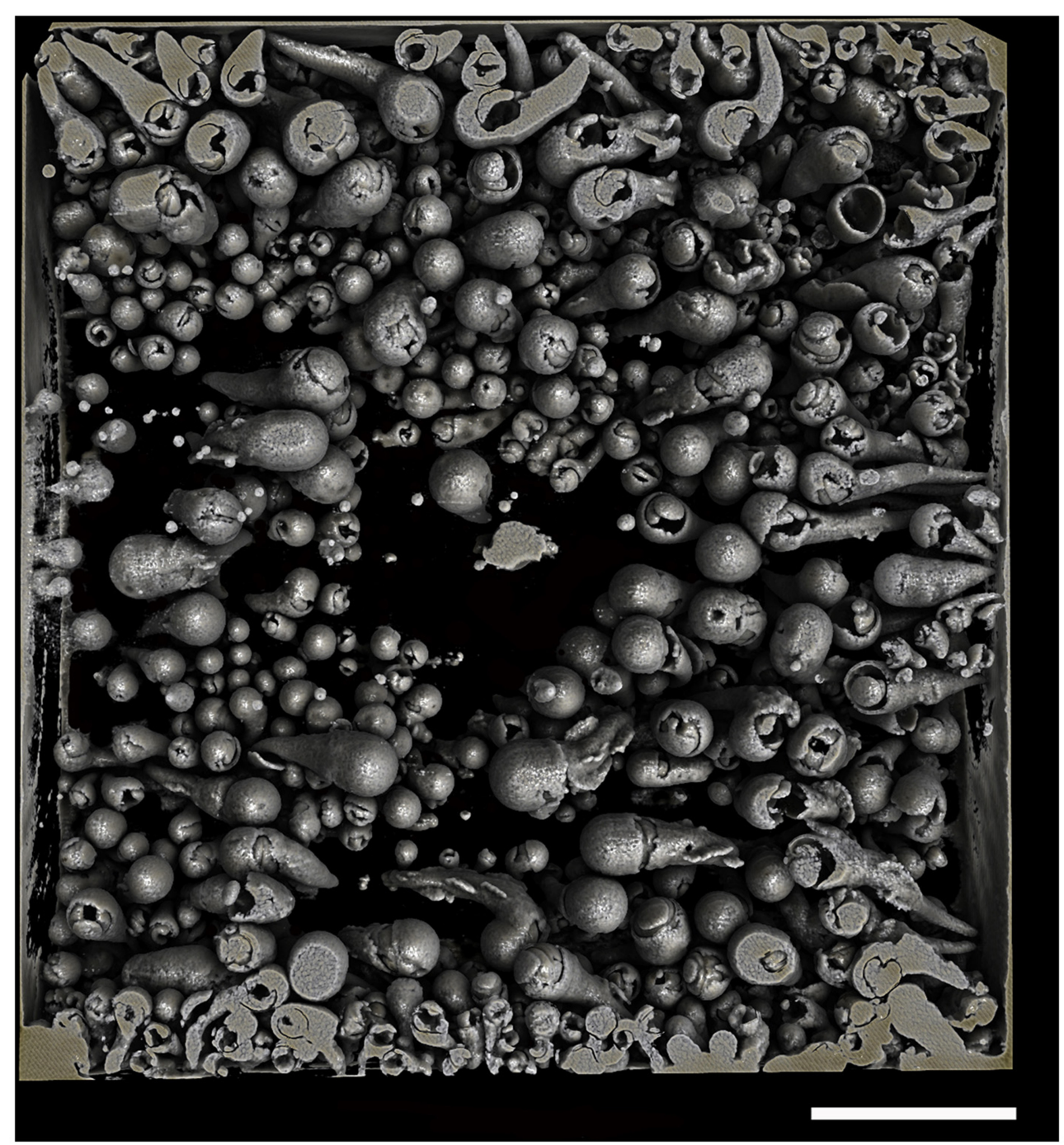

FIGURE 5 |Borings of a population of Xylophaga depalmai. Only the transfer function for air can be seen in this image. Some of the air surrounding the piece of wood was purposefully left in to allow the reader to gauge the shape and size of the wood and the relative position of the borings within the wood. Scale bar is $30 \mathrm{~mm}$. some individuals of that species. Statistically, minimum growth rates of each species were significantly different $(H=9.791, p=$ 0.020 ) (Table 3). X. murrayi had a mean minimum growth rate of $0.007 \pm 0.016 \mathrm{~mm} \mathrm{~d}^{-1}\left(\sim 2.55 \mathrm{~mm}_{\text {year }}{ }^{-1}\right)$, Xylophaga cf. indica had a mean minimum growth rate of $0.008 \pm 0.008 \mathrm{~mm} \mathrm{~d}^{-1}$ ( $2.92 \mathrm{~mm}$ year $^{-1}$ ) and the Xylophaga depalmai populations had a much faster overall mean minimum growth rate of $0.024 \mathrm{~mm}$ $\mathrm{d}^{-1}\left(\sim 8.76 \mathrm{~mm} \mathrm{year}^{-1}\right)$ (Table 3). This did not differ significantly from the growth rates observed for X. depalmai in the much larger dataset in Tyler et al. (2007) $\left(0.0235 \mathrm{~mm} \mathrm{~d}^{-1}\right.$ for spruce and $0.0252 \mathrm{~mm} \mathrm{~d}^{-1}$ for oak). There was no significant difference in minimum growth rates of $X$. depalmai populations with varying deployment lengths or wood types but Tyler et al. (2007) did show a variable growth rate depending on the time of year of deployment. Xyloredo cf. nooi had a minimum growth rate of $0.009 \mathrm{~mm} \mathrm{~d}^{-1}\left(3.29 \mathrm{~mm}\right.$ year $\left.{ }^{-1}\right)$ based on a single observation (Table 3).

\section{WOOD CONSUMPTION RATES}

Micro-CT data was used to measure the percentage volumes of the wood consumed by entire Xylophagaidae populations. The wood bored by Xylophaga murrayi at Coral Seamount was the least bored (1.43-12.62\% in 716 days) (Table 4). At Atlantis Bank, Xylophaga cf. indica consumed $31.16-46.25 \%$ of the wood in 756 days, and at TOTO, Xylophaga depalmai consumed $24.65-50.03 \%$ in $158-182$ days (Table 4 ). The percentage volumes of each block that were made up of borings were significantly different between the three Xylophaga species $(H=6.231$, $p=0.044)$.

The maximum rate of wood degradation by the Xylophaga murrayi population was $6.57 \%$ per year of deployment (Table 4). This is equal to an average value of $0.2351 \pm 0.1186 \mathrm{~cm}^{3}$ being degraded per year per individual of $X$. murrayi, or $\sim 20 \mathrm{~cm}^{3}$ of wood being consumed per year by 100 individuals (Table 4). The maximum rate of wood degradation by the Xylophaga cf. 


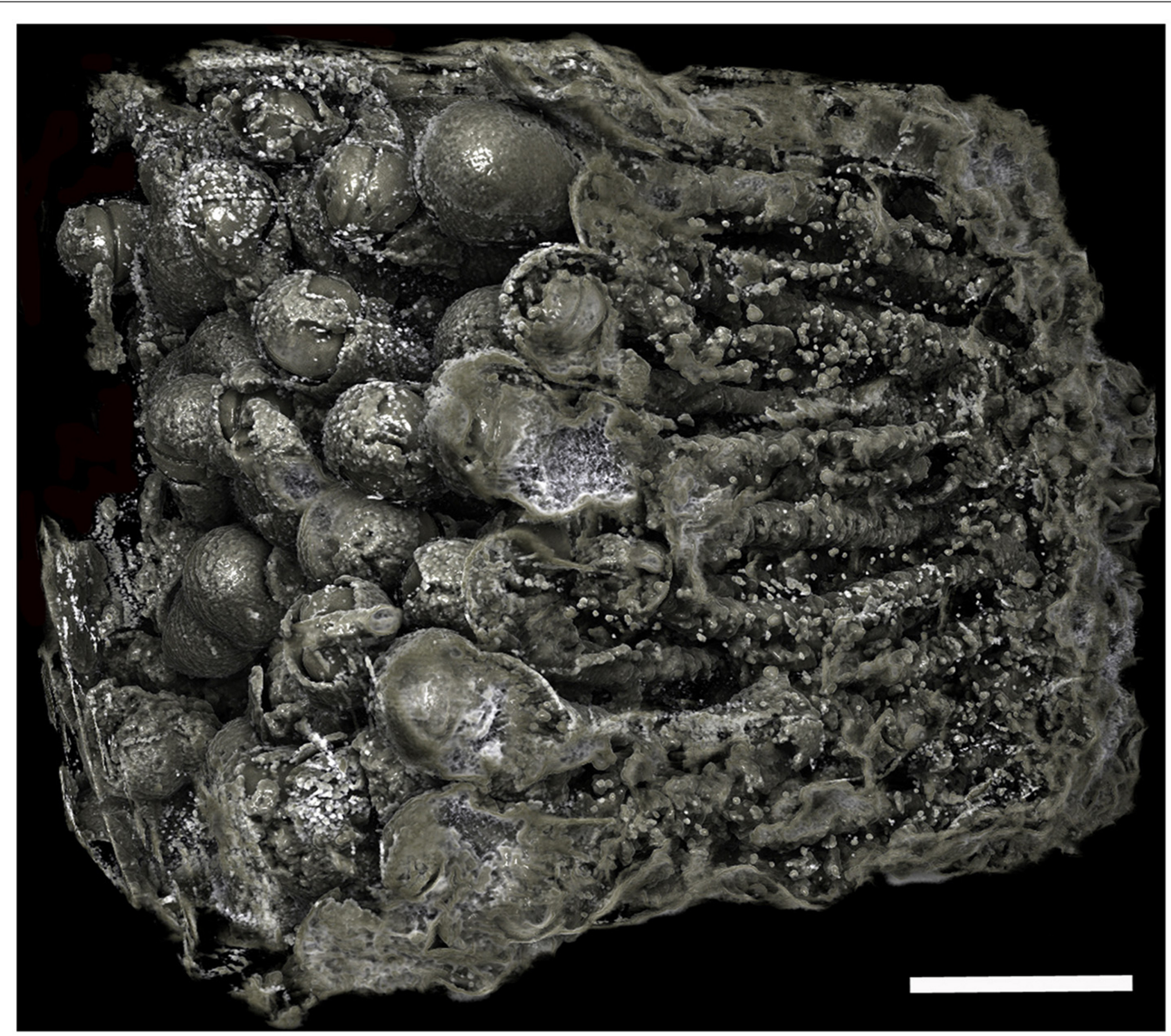

FIGURE 6 | Borings of a population of Xylophaga cf. indica. Only the transfer function for air can be seen in this image. The borings are not as easily distinguished, as the air in the borings was not well defined due to the wood being highly degraded to pulp. Scale bar is $30 \mathrm{~mm}$.

indica population was $22.26 \%$ per year (Table 4 ). This is equal to an approximate average value of $0.6052 \pm 0.0759 \mathrm{~cm}^{3}$ being degraded per year per individual of $X$. cf. indica or $60 \mathrm{~cm}^{3}$ of wood being consumed by 100 individuals per year (Table 4), which is approximately three times the rate of consumption by $X$. murrayi. These values for $X$. cf. indica, however, are probably underestimates as a result of the limitation explained in the Discussion. The mean rate of wood degradation per individual of Xylophaga depalmai per year was $0.084 \%$ from oak and $0.150 \%$ from spruce (Table 4 ). The maximum volume of wood that could be degraded in 6 months by the population of $X$. depalmai would be $51.88 \%$, resulting in the wood being completed degraded before a year had elapsed (Table 4). Blocks deployed for 12 months in TOTO had totally disintegrated at the end of the deployment (Young and Tyler, unpubl. data). This is equal to an approximate average value of $0.4380 \pm 0.1440 \mathrm{~cm}^{3}$ being degraded per year per individual of $X$. depalmai in oak (or $43 \mathrm{~cm}^{3}$ per year per 100 individuals approximately) and $0.6040 \pm 0.108 \mathrm{~cm}^{3}$ in spruce (or $60 \mathrm{~cm}^{3}$ per year per 100 individuals) (Table 4). The rates of wood degradation for each block were significantly different between the three species' populations ( $H=9.346, p=0.009)$, as well as the approximate rates of wood degradation for each individual Xylophaga for the three species $(H=6.846, p=0.033)$.
Mean xylophagaid diameter, mean xylophagaid abundance and mean volume of wood bored per xylophagaid individual per year for each species in this study were correlated with the temperature at the corresponding sample site. There was a weak correlation between mean size and temperature $(r=-0.571$, $p=0.042)$ but there were strong significant correlations between temperature and mean abundance $(r=0.770, p=0.003)$ and mean volume of wood bored per individual per year $(r=0.797$, $p=0.002)$.

\section{DISCUSSION}

\section{DISTRIBUTION, BODY SIZE, SETTLEMENT AND GROWTH RATES OF XYLOPHAGAIDAE}

The Xylophaga species colonizing the deployments in the SWIR have each been found once previously in the Indian Ocean. The localities of Xylophaga murrayi and Xylophaga cf. indica from this present study therefore extend their geographic ranges within the Indian Ocean, increase their depth ranges by $\sim 400 \mathrm{~m}$, and also extend the temperature range for $X$. murrayi $\left(4.3-12.9^{\circ} \mathrm{C}\right)$ (Knudsen, 1961, 1967). Xylophaga depalmai was described from off Florida but is now known to inhabit depths of 30-520 $\mathrm{m}$ from the Bahamas to Massachusetts, USA (Turner, 2002; Tyler et al., 2007). Xyloredo nooi was described from the Bahamas at $1737 \mathrm{~m}$ (Turner, 1972). 


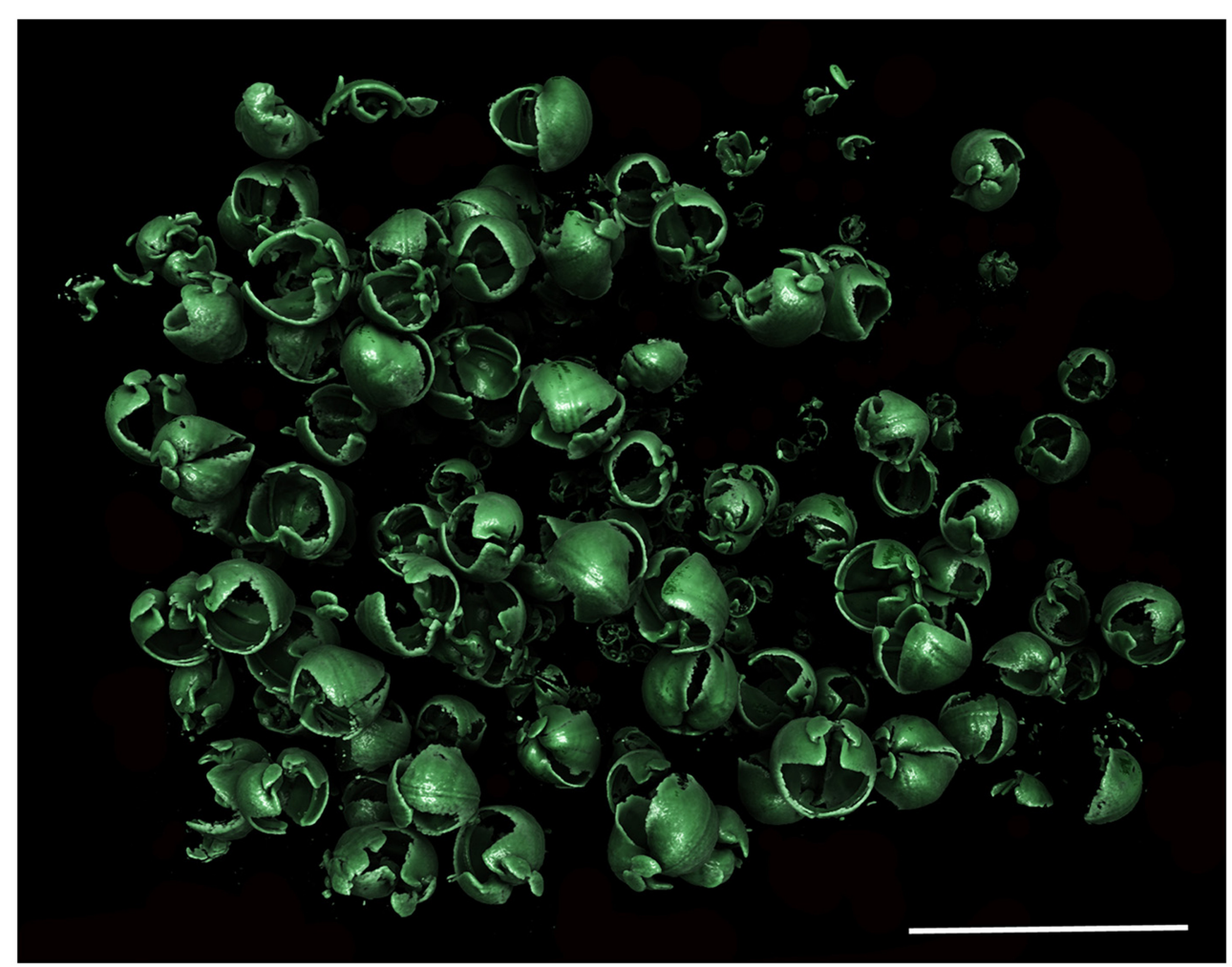

FIGURE 7 | Xylophaga cf. indica population in situ. Only the transfer function for Xylophaga shells can be seen in this image. Scale bar is $30 \mathrm{~mm}$.

With regard to body size as measured by shell diameter, known dimensions of the single specimen of Xylophaga murrayi recorded by Knudsen $(1967)(5.0 \times 5.6 \times 5.7 \mathrm{~mm})$ were similar to those recorded during this study. The one specimen of Xylophaga cf. indica observed by Knudsen (1961) was almost twice as large as many of the specimens observed during our study $(12 \mathrm{~mm}$ diameter compared to $5.13 \mathrm{~mm}$ ). The type specimen of Xylophaga depalmai described by Turner (2002) had a diameter of $9.8 \mathrm{~mm}$, but Tyler et al. (2007) and this study recorded modal diameters between 2.26 and $4.78 \mathrm{~mm}$. Recorded sizes of Xyloredo nooi are slightly larger than that observed here. The absence of a calcareous lining in the boring and the smaller size indicate that this individual may have been a young specimen (Turner, 2002). X. depalmai had the smallest sizes of the four species, which may be as that experiment had the shortest deployment time.

Previous studies have shown species of Xylophaga to have synchronous recruitment (Turner, 1973; Berg et al., 1987), and the unimodal size-frequency distributions of Xylophaga cf. indica and Xylophaga depalmai in our deployments are consistent with such a recruitment pattern. For Xylophaga murrayi, the evidence is less certain as there are two distinct peaks in the size distribution for two of the three blocks examined, perhaps representing two synchronous events. It is noteworthy that the SWIR deployments had been on the seafloor for two years, compared with six months for the Bahamas deployments. Tyler et al. (2007) showed that there was only one recruitment event despite the X. depalmai population reproducing, suggesting that zygotes were advected away from the parents.

Xylophaga murrayi from Coral Seamount (SWIR) had the lowest mean abundance (117 individuals $\mathrm{dm}^{-3}$ ) of all three Xylophaga species (excluding the Xyloredo individual) whereas Xylophaga cf. indica from the more northerly Atlantis Bank (SWIR) had more than double the abundance (300 individuals $\mathrm{dm}^{-3}$ ) of $X$. murrayi. This may have been as a result of environmental setting: the deployment sites on the two seamounts had different substratum types and physical, chemical and biological oceanographic parameters, especially temperature (Rogers et al., 2012). Warmer temperatures at Atlantis Bank may have been more conducive to recruitment than the colder temperatures at Coral Seamount. Predation or differing larval supply to each seamount could have also resulted in these differences. Xylophaga depalmai had the highest abundance of all the localities $\left(\sim 1500\right.$ individuals $\left.\mathrm{dm}^{-3}\right)$, approximately five times higher than $X$. cf. indica and 15 times higher than $X$. murrayi. There was no difference in $X$. depalmai abundances by wood type or deployment length, as was seen by Haderlie (1983).

There was only one specimen of Xyloredo cf. nooi recovered from the deployment in the MCSC. This was initially thought to be as a result of the mooring design, which was dictated by the requirements for suspended oceanographic instruments: the wood was suspended $20 \mathrm{~m}$ above the seafloor and hence potentially into a region of the water column with fewer Xylophagaidae larvae (Haderlie, 1983; Turner, 2002). However, Romano et al. 


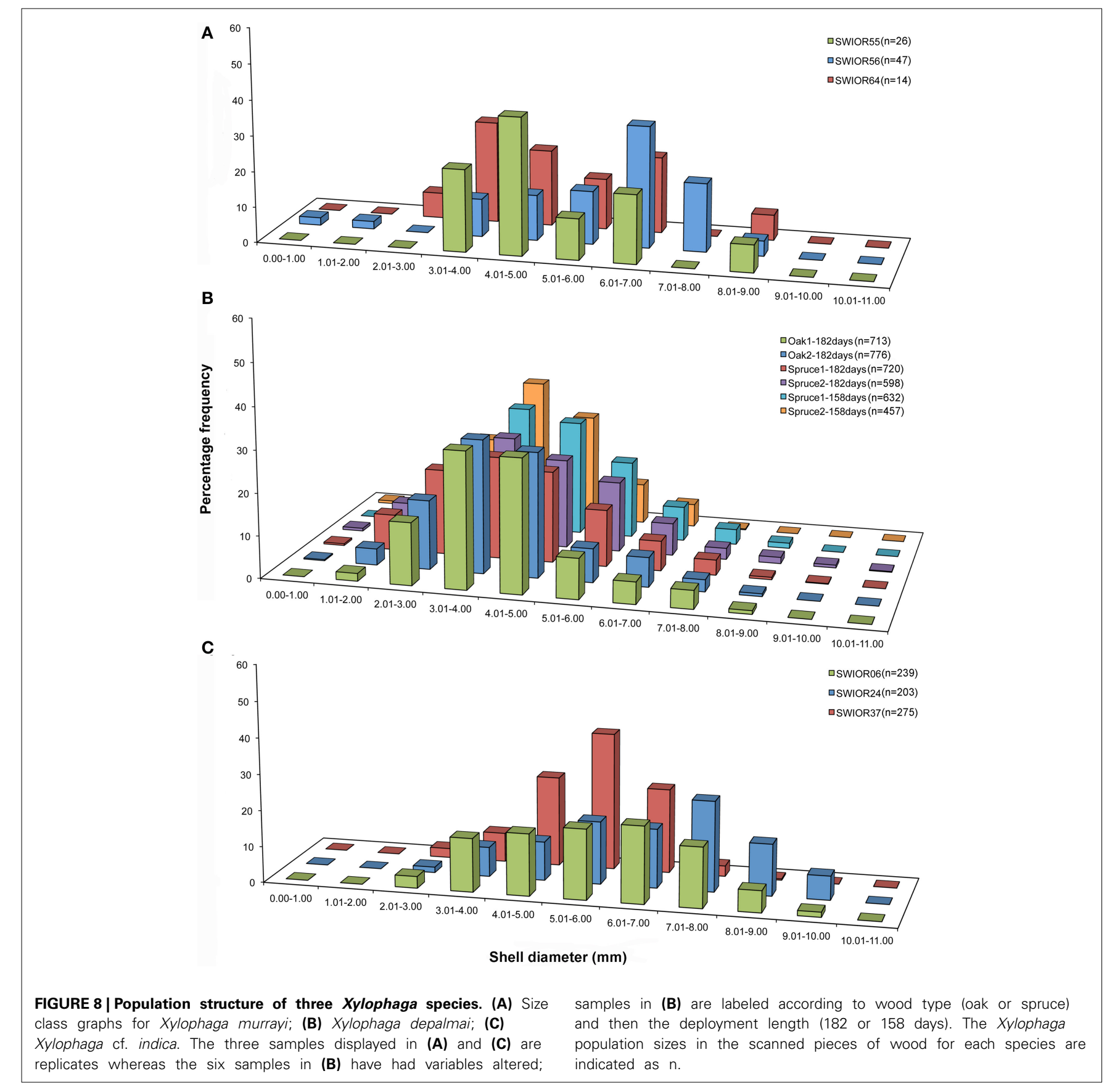

(2013) have shown that wood suspended $20 \mathrm{~m}$ above the seafloor can be colonized heavily by Xylophaga, although that study was conducted in a submarine canyon, which could have greater amounts of turbulence than in the MCSC. The height that Xylophagaidae larvae are able to swim up into the water column may differ according to the species present and the depths of deployments (Romano et al., 2013). The lack of prolific settlement at $4773 \mathrm{~m}$ in the MCSC is probably not a result of the extreme depth, as other xylophagaids (Xylophaga clenchi, $4862 \mathrm{~m}$ and Xylophaga abyssorum, $3950 \mathrm{~m}$ ) have been found at similar depths nearby (Turner, 1955, 2002; Voight, 2009).
Xylophagaidae are known to have very rapid growth rates when compared with other non-chemosynthetic deep-sea bivalves (e.g., Tindaria callistiformis $=8.4 \mathrm{~mm} / 100$ years) (Turekian et al., 1975). Xylophaga murrayi, Xylophaga cf. indica and Xyloredo cf. nooi had similar minimum growth rates but Xylophaga depalmai grew approximately three times faster (Tyler et al., 2007). The difference in growth rates between $X$. depalmai and the other species of Xylophagaidae in this study may be explained by the S-shaped growth curve (Romey et al., 1994). As $X$. depalmai were growing for a maximum of 158-182 days, whereas the other species were growing for a maximum of 756 


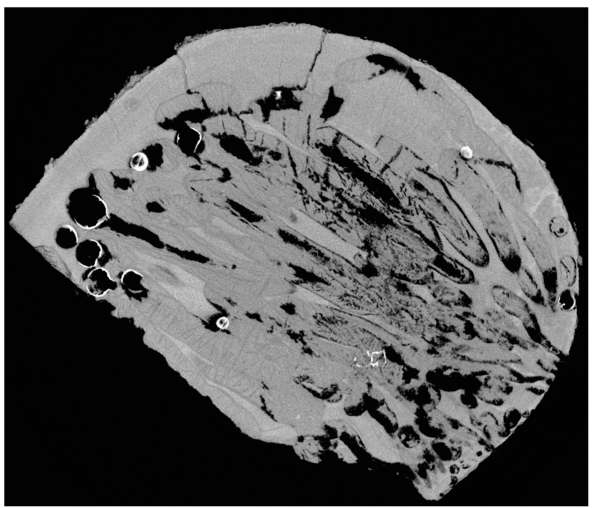

FIGURE 9 | Cross-section through a piece of wood deployed at Atlantis Bank, SWIR. This image shows a problem faced when using micro-CT to estimate volume of unbored wood in samples that contain a large amount of wood pulp (dark gray) created during the Xylophagaidae boring process. The outlines of burrows in unbored wood can clearly be seen, as well as the air (black) and Xylophaga indica shells (white).

days, the Bahamian species may still have been in the rapid growth phase rather than the plateau phase as with the other species. Romano et al. (2013) observed the mean growth rate was $0.070 \mathrm{~mm} \mathrm{~d}^{-1}$ in the first three months of deployment, but then slowed in the next nine months to $0.021-0.016 \mathrm{~mm} \mathrm{~d}^{-1}$. Xylophaga atlantica has growth rates that differed with crowding: $0.085 \mathrm{~mm} \mathrm{day}^{-1}$ in individuals that settled at the deployment beginning and $0.031 \mathrm{~mm} \mathrm{day}^{-1}$ in individuals that settled one year after deployment (Romey et al., 1994).

\section{THE EFFECT OF XYLOPHAGAIDAE ON WOOD}

The shape of xylophagaid borings is very characteristic, and closest to the shape of the "Prince Rupert's Drop," however, our study has also shown that the borings of different species vary in morphology and size. Volumes of xylophagaid borings have not been reported previously but lengths have: Turner (1973) reported 20$\mathrm{mm}$ burrows in an undescribed Xylophaga sp., comparable with the lengths observed in Xylophaga murrayi and Xylophaga depalmai. Turner (1973) however, proposed overcrowding to explain these burrow sizes; that may be the case for $X$. depalmai but not for X. murrayi in this study. Turner (2002) noted that Xylophaga profunda had borings of $45-50 \mathrm{~mm}$ length or approximately twice the shell depth, fitting in the middle of the range of boring sizes observed in this study. Dons (1940) observed similar sized borings $(50 \mathrm{~mm})$ in Xylophaga dorsalis.

How much wood can Xylophagaidae eat? This study has demonstrated the variability in the rates of wood degradation by xylophagaids, however we are unsure whether this is as a result of intrinsic variables relating to the species themselves (e.g., metabolic rates) or extrinsic variables (e.g., wood hardness, wood size and shape etc.). The percentage of wood bored by the populations of each Xylophaga species was related to the abundance of animals and may also be related to different-sized wood blocks with regard to surface area to volume ratios, which will affect levels of Xylophaga recruitment. Xylophaga murrayi had 14-26 individuals present in each sample and this corresponded to $1-13 \%$ of wood being bored. Xylophaga cf. indica had 203-239 borings in each sample corresponding to $31-46 \%$ of wood being bored. However, Xylophaga depalmai had the highest frequency of borings (457-776 borings) but the amount of wood consumed $(25-50 \%)$ was similar to that of $X$. cf. indica. This was normalized by calculating the mean individual boring rate per day for each species, and it was then apparent that per individual, $X$. cf. indica was the most efficient borer and $X$. depalmai had the highest percentage of wood bored because of the large population size. An $X$. depalmai individual could bore $0.4380 \mathrm{~cm}^{3}$ in oak and $0.6040 \mathrm{~cm}^{3}$ in spruce and $X$. cf. indica individual bored $0.6052 \mathrm{~cm}^{3}$ in a year (though this was probably an underestimate). An individual of $X$. murrayi was able to bore $0.2351 \mathrm{~cm}^{3}$ of wood in a year. Even though calculations show individual boring efficiency was only marginally higher in $X$. cf. indica than $X$. depalmai, the figure may in fact be much higher due to methodological limitations after visual inspection of the wood.

After observing the wood and the micro-CT scans, we believe that the percentages of wood bored by Xylophaga cf. indica are underestimated. The wood inhabited by $X$. cf. indica was so heavily bored that the blocks were disintegrating and could be crushed by hand, whereas the wood bored by Xylophaga depalmai had many apertures covering the surfaces but was still solid. This would indicate that the percentage volume bored by $X$. cf. indica (46\%) should be much higher than X. depalmai (50\%). This inaccuracy may have been caused by the inability of the micro-CT scanner to distinguish between wood pulp within burrows created by the boring activity of $X$. cf. indica and solid unbored wood, resulting in much higher volumes of "solid" wood being recorded (Figure 9). The borings (shown as air) created by Xylophaga murrayi and Xylophaga depalmai were well defined and did not contain wood pulp, whereas those air spaces created by $X$. cf. indica appear to be more "rugged" indicating the presence of small particles of wood pulp instead of the smooth boring edges (Figures 4-6, 9). Similar fast consumption rates have been observed in previous studies: Turner (1973) noted wood blocks disintegrating while being collected by DSV Alvin after 104 days off Massachusetts, and Haderlie (1983) noted panels disintegrating after 4-6 months of deployment.

A positive relationship between water temperature, abundance and wood consumption was observed. At the coldest sites (Coral Seamount and MCSC), the wood was the least heavily colonized and bored. Warmer temperatures may be more conducive to recruitment and survival of Xylophagaidae larvae accounting for the higher degradation rates in Xylophaga cf. indica and Xylophaga depalmai. Metabolic rates of animals are also known to be higher in warmer temperatures, which may be a factor in the higher degradation rates in those two species. Recent observations of the absence of wood-eating fauna such as Xylophaga from Antarctic waters (Glover et al., 2013) are also supportive of this, although the authors hypothesized that this was due to lack of larval input rather than cold temperatures.

\section{CONCLUSION}

Micro-CT has provided a new, non-destructive method to gain insight into Xylophagaidae ecology and their use of wood 
as a resource, including quantitative measurements of their wood degradation rates. This study has also reaffirmed that Xylophagaidae are keystone species in wood-fall ecosystems and are vitally important in the remineralization of wood in the deep sea. If future studies can be directed into estimating how much wood enters the deep sea and assessing its importance as a food resource, our data can be used to directly estimate the overall remineralization rates for terrestrial wood inputs in deep-sea areas with known presence of Xylophagaidae.

\section{AUTHOR CONTRIBUTIONS}

JC and KK were integral in the deployment and recovery of the SWIR experiments, PT and CY in the deployment and recovery, as well as the supply of some data from the TOTO experiments, and DA, AG, and JC in the deployment and recovery of the MCSC experiments. DA and AG processed the samples at the Natural History Museum prior to micro-CT scanning. DA, DS, and FA were responsible for micro-CT scanning and processing. DA did the data analysis and wrote the bulk of the manuscript with help from all co-authors.

\section{ACKNOWLEDGMENTS}

We wish to thank the Masters and crews of the EAF Nansen Project Fridtjof Nansen cruise 2009410 and the NERC cruise RRS James Cook JC066, the UK National Marine Facilities staff at NOC and the ROV Kiel 6000 team for their tremendous support during the fieldwork at the Southwest Indian Ocean Ridge. We also thank the Masters and crews of the research vessels RRS James Cook JC044 and RRS Discovery D374 during fieldwork in the Mid-Cayman Spreading Centre. Further thanks to the scientists on board during all voyages. We are especially grateful to Fiona Dove for size data generated from the TOTO program, Dr. Nicholas Higgs and Dr. Helena Wiklund for helping with samples at the Natural History Museum London, Dr. Janet Voight for helping with identification of the Xyloredo, and Professor Alex Rogers for his help with the SWIR samples. We also acknowledge Dr. Leigh Marsh for pointing out the similarity of the boring shape to a "Prince Rupert's Drop." The deployment and collection of the wood packages at the Southwest Indian Ridge seamounts was funded through NERC Grant NE/F005504/1 and GEF Grant 3138 implemented by the United Nations Development Programme. This project was part of the Southwest Indian Ocean Seamounts Project (www.iucn. org/marine/seamounts) supported by the Natural Environment Research Council of the UK, the EAF Nansen Project, the Food and Agriculture Organization of the United Nations, the Global Environment Facility, the International Union for the Conservation of Nature and the Agulhas Somali Current Large Marine Ecosystem Programme (ASCLME). The deployment and collection of the wood packages at the Mid-Cayman Spreading Centre was funded by the UK NERC award NE/F017774/1. The deployment and collection of the wood at the Bahamas location was completed under NSF grants OCE-9116560, OCE9633784 and OCE-0118733. This is UH SOEST publication number 9259. All funders had no roles in study design, data collection and analysis, decision to publish, or preparation of the manuscript.

\section{REFERENCES}

Amon, D. J., Copley, J. T., Dahlgren, T. G., Horton, T., Kemp, K. M., Rogers, A. D. et al. (in review). Observations of fauna attending opportunistic deployments from two seamounts on the Southwest Indian Ridge. Deep Sea Res. II Top. Stud. Oceanogr.

Berg, C. J. Jr., Butman, B., Early, J. A., and Turner, R. D. (1987). Seasonal recruitment of marine invertebrates to hard substrates on Georges Bank and the eastern continental shelf of the United States. Nautilus 101, 19-24.

Bernardino, A. F., Smith, C. R., Baco, A., Altamira, I., and Sumida, P. Y. G. (2010) Macrofaunal succession in sediments around kelp and wood falls in the deep NE Pacific and community overlap with other reducing habitats. Deep-Sea Res. I Oceanogr. Res. Pap. 57, 708-723. doi: 10.1016/j.dsr.2010.03.004

Bienhold, C., Pop Ristova, P., Wenzhàfer, F., Dittmar, T., and Boetius, A. (2013). How deep-sea wood falls sustain chemosynthetic life. PLOS ONE 8:e53590. doi: 10.1371/journal.pone.0053590

Connelly, D. P., Copley, J. T., Murton, B. J., Stansfield, K., Tyler, P. A., German, C. R., et al. (2012). Hydrothermal vent fields and chemosynthetic biota on the world's deepest seafloor spreading centre. Nat. Commun. 3, 620. doi: $10.1038 /$ ncomms 1636

Crisp, D. J., Jones, L. W. G., and Watson, W. (1953). Use of X-Ray Stereoscopy for examining Shipworm Infestation in vivo. Nature 172, 408-409. doi: 10.1038/172408b0

Distel, D. L., and Roberts, S. J. (1997). Bacterial endosymbionts in the gills of the deep-sea wood-boring bivalves Xylophaga atlantica and Xylophaga washingtona. Biol. Bull. 192, 253-261. doi: 10.2307/1542719

Dons, C. (1940). Marine boreorganismer 111. Vekst og voksemite hos Xylophaga dorsalis. Ibid 13, 76-78.

Duperron, S., Laurent, M. C. Z., Gaill, F., and Gros, O. (2008). Sulphur-oxidizing extracellular bacteria in the gills of Mytilidae associated with wood falls. FEMS Microbiol. Ecol. 63, 338-349. doi: 10.1111/j.1574-6941.2008.00438.x

Feldkamp, L. A., Davis, L. C., and Kress, J. W. (1984). Practical cone-beam algorithm. J. Opt. Soc. Am. 1, 612-619. doi: 10.1364/JOSAA.1.000612

Gage, J. D. (2003). "Food inputs, utilization, carbon flow and energetics," in Ecosystems of the Deep Oceans, ed. P. A. Tyler. (Rotterdam: Elsevier), 313-380.

Glover, A. G., Wiklund, H., Taboada, S., Avila, C., Cristobo, J., Smith, C. R., et al. (2013). Bone-eating worms from the Antarctic: the contrasting fate of whale and wood remains on the Southern Ocean seafloor. Proc. R. Soc. B Biol. Sci. 280, 20131390. doi: 10.1098/rspb.2013.1390

Haderlie, E. C. (1983). Depth distribution and settlement times of the molluscan wood borers Bankia setacea (Tryon, 1863) and Xylophaga washingtonia Bartsch, 1921 in Monterey Bay. Veliger 25, 339-342.

Harvey, R. (1996). Deep water Xylophagaidae (Pelecypoda: Pholadacea) from the North Atlantic with descriptions of three new species. J. Conchol. 35, 473-482.

Higgs, N. D., Glover, A. G., Dahlgren, T. G., and Little, C. T. S. (2010). Using computed-tomography to document borings by Osedax mucofloris in whale bone. Cahiers de Biologie Marine 51, 401-405.

Higgs, N. D., Glover, A. G., Dahlgren, T. G., and Little, C. T. S. (2011a). Boneboring worms: Characterizing the morphology, rate, and method of bioerosion by Osedax mucofloris (Annelida, Siboglinidae). Biol. Bull. 221, 307-316. doi: $10.2307 / 23080081$

Higgs, N. D., Little, C. T. S., Glover, A. G., Dahlgren, T. G., Smith, C. R., and Dominici, S. (2011b). Evidence of Osedax worm borings in Pliocene ( $\sim 3 \mathrm{Ma}$ ) whale bone from the Mediterranean. Hist. Biol. 24, 269-277. doi: $10.1080 / 08912963.2011 .621167$

Kiel, S., Goedert, J. L., Kahl, W. A., and Rouse, G. W. (2010). Fossil traces of the bone-eating worm Osedax in early Oligocene whale bones. Proc. Natl. Acad. Sci. U.S.A. 107, 8656-8659. doi: 10.1073/pnas.1002014107

Knudsen, J. (1961). The bathyal and abyssal Xylophaga (Pholadidae, Bivalvia). Galathea Rep. 5, 163-209.

Knudsen, J. (1967). The deep-sea Bivalvia. John Murray Exped. Sci. Rep. 11, 237-343.

Limaye, A. (2006). "Drishti - volume exploration and presentation tool," in Poster Presentation Vis 2006 (Baltimore, MD).

Rogers, A. D., Boersch-Supan, P. H., Chen, C., Chivers, A., Copley, J. T., Djurhuus, A., et al. (2012). "Benthic biodiversity of seamounts in the southwest Indian Ocean," in Cruise Report "RRS James Cook" Southern Indian Ocean Seamounts (IUCN/UNDP/ASCLME/NERC Cruise 66).

Romano, C., Voight, J. R., Company, J. B., Plyuscheva, M., and Martin, D. (2013). Submarine canyons as the preferred habitat for wood-boring 
species of Xylophaga (Mollusca, Bivalvia). Prog. Oceanogr. 118, 175-187. doi: 10.1016/j.pocean.2013.07.028

Romey, W. L., Bullock, R. C., and De Alteris, J. T. (1994). Rapid growth of a deepsea wood-boring bivalve. Cont. Shelf Res. 14, 1349-1359. doi: 10.1016/02784343(94)90052-3

Rouse, G. W., Goffredi, S. K., and Vrijenhoek, R. C. (2004). Osedax: Bone-eating marine worms with dwarf males. Science 305, 668. doi: 10.1126/science. 1098650

Turekian, K. K., Cochran, J. K., Kharkar, D. P., Cerrato, R. M., Rimas Vaisnys, J., Sanders, H. L., et al. (1975). Slow growth rate of a deep-sea clam determined by 228Ra chronology. Proc. Natl. Acad. Sci. U.S.A. 72, 2829-2832. doi: 10.1073/pnas.72.7.2829

Turner, R. D. (1955). The family Pholadidae in the Western Atlantic and the Eastern Pacific, part II: Martesiinae, Jouannetiinae and Xylophaginae. Johnsonia: Monogr. Mar. Moll. Western Atlantic 3, 65-160.

Turner, R. D. (1972). Xyloredo, a new teredinid-like abyssal wood-borer (Mollusca, Pholadidae, Xylophagainae). Breviora 397, 7-9; 16-18.

Turner, R. D. (1973). Wood-boring bivalves, opportunistic species in the deep sea. Science 180, 1377-1379. doi: 10.1126/science.180.4093.1377

Turner, R. D. (1977). Wood, mollusks, and deep-sea food chains. Bull. Am. Malacol. Union 213, 13-19.

Turner, R. D. (2002). On the subfamily Xylophaginae (Family Pholadidae, Bivalvia, Mollusca). Bull. Museum Compar. Zool. 157, 223-307.

Tyler, P. A., Young, C. M., and Dove, F. (2007). Settlement, growth and reproduction in the deep-sea wood-boring bivalve mollusc Xylophaga depalmai. Mar. Ecol. Prog. Ser. 343, 151-159. doi: 10.3354/meps06832

Voight, J. R. (2008). Deep-sea wood-boring bivalves of Xylophaga (Myoida: Pholadidae) on the Continental Shelf: a new species described. J. Mar. Biol. Assoc. U.K. 88, 1459-1464. doi: 10.1017/S0025315408002117

Voight, J. R. (2009). Diversity and reproduction of near-shore vs offshore woodboring bivalves (Pholadidae: Xylophagainae) of the deep eastern Pacific Ocean, with three new species. J. Moll. Stud. 75, 167-174. doi: 10.1093/mollus/ eyp012
Voight, J. R., and Segonzac, M. (2012). At the bottom of the deep blue sea: a new wood-boring bivalve (Mollusca, Pholadidae, Xylophaga) from the Cape Verde Abyssal Plain (subtropical Atlantic). Zoosystema 34, 171-180. doi: $10.5252 / \mathrm{z} 2012 \mathrm{n} 1 \mathrm{a} 8$

Vrijenhoek, R. C., Collins, P., and Van Dover, C. L. (2008). Bone-eating marine worms: habitat specialists or generalists? Proc. R. Soc. B Biol. Sci. 275, 1963-1964. doi: 10.1098/rspb.2008.0350

Wolff, T. (1979). Macrofaunal utilization of plant remains in the deep sea. Sarsia $64,117-136$.

Yang, J. C., Madupu, R., Durkin, A. S., Ekborg, N. A., Pedamallu, C. S., Hostetler, J. B., et al. (2009). The complete genome of Teredinibacter turnerae: an intracellular endosymbiont of marine wood-boring bivalves (shipworms). PLOS ONE 4:e6085. doi: 10.1371/journal.pone.0006085

Conflict of Interest Statement: The authors declare that the research was conducted in the absence of any commercial or financial relationships that could be construed as a potential conflict of interest.

Received: 14 October 2014; paper pending published: 13 January 2015; accepted: 03 February 2015; published online: 14 April 2015.

Citation: Amon DJ, Sykes D, Ahmed F, Copley JT, Kemp KM, Tyler PA, Young CM and Glover AG (2015) Burrow forms, growth rates and feeding rates of wood-boring Xylophagaidae bivalves revealed by micro-computed tomography. Front. Mar. Sci. 2:10. doi: 10.3389/fmars.2015.00010

This article was submitted to Deep-Sea Environments and Ecology, a section of the journal Frontiers in Marine Science.

Copyright (c) 2015 Amon, Sykes, Ahmed, Copley, Kemp, Tyler, Young and Glover. This is an open-access article distributed under the terms of the Creative Commons Attribution License (CC BY). The use, distribution or reproduction in other forums is permitted, provided the original author (s) or licensor are credited and that the original publication in this journal is cited, in accordance with accepted academic practice. No use, distribution or reproduction is permitted which does not comply with these terms. 